J. Product. \& Dev., 15(3):377- 394 (2010)

\title{
EFFECT OF BIO-PESTICIDES AND CHEMICAL FERTILIZERS ON GROWTH, YIELD AND TUBER QUALITY OF POTATO, AS WELL AS, CONTROL OF POTATO LATE BLIGHT UNDER SANDY SOIL CONDITIONS
}

\author{
E. H. Abou El-Salehein ${ }^{1}$; K. Bahary ${ }^{2}$; A.I. Sharaf ${ }^{3}$ and E.E. Abd \\ El-Moula ${ }^{4}$ \\ 1. Plant Production Dept., Efficient Productivity Inst., Zagazig Univ., Egypt \\ 2. Plant Protection Dept., Fac. Agric. $7^{\text {th }}$ October Univ., Ben Walid, Libya \\ 3. Soil Science and Water Dept., Fac. Agric. El Shatbi, Alex. Univ., Egypt \\ 4. Agronomy Dept., High Job Center foully Jobs, Zawia, Libya.
}

\section{ABSTRACT}

The present work was carried out to study the effect of some biopesticides (plant guard and Agarin potato) and $\mathrm{N}+\mathrm{P}_{2} \mathrm{O}_{5}+\mathrm{K}_{2} \mathrm{O}$ levels $(0+0+0,10+10+20,20+20+40,40+40+80) \mathrm{kg} / \mathrm{fad}$., on growth, chemical composition of whole plant, tuber quality and yield of potato, as well as, control of potato late blight under sandy soil conditions during two growing seasons of 2007 and 2008.

The results showed that treatment with biopesticides, plant guard which contains the fungus Tricoderma harzianum and Agarin potato which contains the bacterium Bacillus thuringiensis, significantly increased plant growth, tuber yield and its nutritional value in most studied characters and decreased the percentage of natural infection of Phytophthora infestans.

The plant guard which contains the fungus T. harzianum, being the most effective and favorable treatment in most cases.

Furthermore, application of the used level of $\mathrm{N}+\mathrm{P}_{2} \mathrm{O}_{5}+\mathrm{K}_{2} \mathrm{O}$ fertilizer at 20+20+40 kg/fad., respectively resulted in the maximum values in most studied characters of plant growth chemical composition, yield and its quality of potato, but increasing the level of $\mathrm{N}+\mathrm{P}_{2} \mathrm{O}_{5}+\mathrm{K}_{2} \mathrm{O}$ increased the percentage of natural infection of Phytophthora infestans.

Generally, the interaction between the plant guard and $\mathrm{N}+\mathrm{P}_{2} \mathrm{O}_{5}+\mathrm{K}_{2} \mathrm{O}$ at $20+20+40 \mathrm{~kg} / \mathrm{fad}$., respectively, being the most effective and favorable treatment in most cases.

Keywords: Potato, biopesticides, NPK. 


\section{INTRODUCTION}

Potato (Solanum tuberosum L.) is one of the most important vegetable crops in the world.

The need for chemical fungicides and pesticides usage critically increased to eliminate fungal pathogens.

This chemical control has been recommended as alternative and quick mean of disease control by Ghanim, 1993. On the other hand, traditionally, $\mathrm{N}, \mathrm{P}$ and $\mathrm{K}$ fertilizers have been used to correct the deficiency problems of those, but these application are not entirely satisfactory solution because of the limited availability, its high cost, as well as, it is considered as a factor of pollution for the environment and human race health (Hong et al., 2001).

Nowadays, using the bio-pesticides, such as plant guard which contains T.harzianum and potato Agarin which contains Bacillus thuringiensis as a biological control agents to control the diseases such as blight has been recommended (Shalaby and Atia, 1996, Aly et al., 2000, Atia et al., 2002, and Atia, 2005). The other benefit of those biopesticides is that they are used as a bio-fertilizer, beside mineral fertilizers for the plant nutritional requirements causing minimize the use of chemical fertilizers, as well as, increased plant growth, chemical composition and tuber yield and its quality (Abdel-kader, 1997; Abou Hussein et al., 2002; Ali et al.,2003 and Fekry et al ., 2003).

Nitrogen is an essential element during the early stages of plant growth for rapid plant growth (Burton, 1989). Plant height of potato plants significantly increased with increasing nitrogen application levels (Meena and Gupta, 1996 and El-Banna et al., 2004).In addition, nitrogen application enhanced tuber phosphorus percentage and uptake (Kaszaki et al., 1995) and increased $\mathrm{N}$ and $\mathrm{K}$ contents of tuber (Anadousi et al., 1998).

Moreover, the higher nitrogen rate increased the tuber size and weight as well as yield (Arsenault et al., 2001) and tuber $\mathrm{N}$ concentration (Behanger et al., 2002)

Applications of NPK fertilizers increased starch of potato tuber content (Shatilov and Sharov, 1992) and increased the percentage of N, P and $\mathrm{K}$ in potato leaves and total carbohydrates in potato tuber as well as potato tuber yield (Khalil, 1990; Javed et al., 1995 and Abou Hussein et al., 2002).

Therefore, the objective of this investigation is a comparative study the effect of biopesticides, NPK fertilizers and their interaction on the growth, yield and quality of potato plants under sandy soil conditions. 


\section{MATERIALS AND METHODS}

Two field experiments were carried out during the two successive growing seasons on potato cv. Dimont. Potato tuber seeds were planted on $1^{\text {st }}$ and $2^{\text {nd }}$ of September,2007 and 2008,respectively in private farm at El-Zawia Zone, Libya. Some physical and chemical properties of the experimental soil were as shown in Table, 1 .

Table 1. Some physiological and chemical properties of the experimental soil.

\begin{tabular}{|c|c|c|c|c|c|c|c|c|c|}
\hline \multirow{2}{*}{$\begin{array}{l}\mathbf{p H} \\
7.6 \\
\end{array}$} & \multirow{2}{*}{$\begin{array}{l}\text { EC } \\
0.57 \\
\end{array}$} & \multicolumn{8}{|c|}{ Soluble cations and anions (megL-1) } \\
\hline & & \multicolumn{4}{|c|}{ Cations } & \multicolumn{4}{|c|}{ Anions } \\
\hline & & $\mathbf{C A}++$ & Mg++ & $\mathrm{Na}++$ & $\mathbf{K}++$ & CO3- & HCO3- & Cl- & SO4- \\
\hline & & 1.73 & 1.04 & 3.04 & 0.02 & - & 0.55 & 4.91 & 0.3 \\
\hline \multicolumn{4}{|c|}{ Particle size distribution } & $\begin{array}{l}\text { Texture } \\
\text { class }\end{array}$ & Avail & ble (PI & & & \\
\hline $\begin{array}{c}\text { Coarse } \\
\text { sand } \\
\%\end{array}$ & $\begin{array}{c}\text { Fine } \\
\text { sand } \\
\%\end{array}$ & Silt \% & $\begin{array}{c}\text { Clay } \\
\%\end{array}$ & \multirow[t]{2}{*}{$\begin{array}{l}\text { Sandy } \\
\text { clay } \\
\text { loam }\end{array}$} & $\mathbf{N}$ & $\mathbf{P}$ & $\mathbf{K}$ & & \\
\hline 1.62 & 12.60 & 20.70 & 62.29 & & 16 & 129 & 327 & & \\
\hline
\end{tabular}

The experiment was conducted in split plot design of randomized blocks, with three replicates to investigate response of potato growth, yield and some chemical contents, in foliage and tubers ,to biopesticides( plant guard and Agarin potato) and different levels of NPK, as follows:

\section{Biopesticides:}

1-Control (without any addition), only tap water.

2-Plant guard which contains the fungus Tricoderma harzianum (300 g./fad.). 3-Agarin potato which contains the bacterium Bacillus thuringiensis (300 g./fad.)

Tricoderma harzianum was obtained from the Dept. Plant Path., Res. Inst. of Agric. Res. Centre ,Giza,Egypt. Bacillus thuringiensis was isolated from Agarin potato.

Tricoderma harzianum was grown on malt extract liquid medium for 15 days at $25^{\circ} \mathrm{C}$. Spore suspension was adjusted by hemicytometer slide $4 \mathrm{x}$ $10^{8}$ conidia ml.

Bacillus thuringiensis was grown on nutrient broth medium over night at $28^{0} \mathrm{C}$, and cell suspension adjusted $10^{7} \mathrm{cfu} / \mathrm{ml}$. 
Potato tuber seeds were treated with each of biopesticides, Tricoderma harzianum or / and Bacillus thuringiensis (one $\mathrm{ml}$ of spore suspension of each), which were added to $1 \%$ Arabic gum solution as an adhesive material mixed with the treated tuber of potato and left ten min. before sowing( Fekry et al., 2003).

\section{The level of NPK fertilizers:}

1- Control (without NPK, $0+0+0$ ).

2- $10+10+20 \mathrm{~kg} /$ fad. $\mathrm{N}, \mathrm{P}_{2} \mathrm{O}_{5}$ and $\mathrm{K}_{2} \mathrm{O}$ ).

3- 20+ $10+20 \mathrm{~kg} /$ fad. $\mathrm{N}, \mathrm{P}_{2} \mathrm{O}_{5}$ and $\mathrm{K}_{2} \mathrm{O}$ ).

4- 40+ 40+80 kg/fad. $\mathrm{N}, \mathrm{P}_{2} \mathrm{O}_{5}$ and $\mathrm{K}_{2} \mathrm{O}$ ).

The used biopesticides were assigned in the main plots and the four levels of NPK fertilizers were in sub plots.

The fertilizers were applied in the form of ammonium sulphate (20. $5 \% \mathrm{~N})$, calcium superphosphate $\left(16 \% \mathrm{P}_{2} \mathrm{O}_{5}\right)$ and potassium sulphate $(48 \%$ $\mathrm{K}_{2} \mathrm{O}$ ). The area of sub-plot was $8.4 \mathrm{~m}^{2}$ (4 ridges of $3.5 \mathrm{~m}$. long and $0.6 \mathrm{~m}$. width), seeds were sown on one side ridge at $40 \mathrm{~cm}$ apart. One guard row was left without planting between each two plots.

The different amount of fertilizers was added at two equal doses after four and eight weeks from sowing.

The other cultural procedures of growing potato were practiced usually followed in the commercial production of tuber yield of potato.

The following data were recorded at 75 days after planting in representative samples of 5 plants from each plot as follows:

1- Plant growth parameters: Plant height $(\mathrm{cm})$, number of aerial stems/plant, number of leaves/plant and dry weight of plant parts (gm), i.e. roots, shoots, tubers and stems and total dry weight.

2-Percentage of natural infection with Phytophthora infestans: The naturally infected potato plants were recorded in each plot and Disease incidence was calculated on the base of:

Percentage of infection $=$ No. of infected plants $/$ Total plants $\mathrm{x} 100$

3 - Chemical composition of whole plant: Total nitrogen was determined using micro-Kjildahl method (A.O.A., 1990). Phosphorus was determined calorimetrically according to Jackson (1973) method and potassium was estimated using a flame photometer (Ranganna, 1979).

4 - Yield and its components: At the harvest time (after 120 days from planting) number of tubers/plant, average weight of tubers/plant, average 
weight of tubers $(\mathrm{gm})$, small tuber yield $(3.5$ and $6.4 \mathrm{~cm})$ and large tubers yield (above $6.5 \mathrm{~cm}$ ) were determined.

5 -Tuber quality: At harvest time (after 120 days from planting) N, P, and K $\%$ were determined using the methods described above mentioned, total carbohydrates, starch and total sugars were determined according to the methods of Michel et.al. (1956).

\section{Statically analysis:}

The obtained data were statistically analyzed according to Snedecor and Cochran (1980) to compare treatments by the least significant differences (LSD) at $5 \%$ probability.

\section{RESULTS AND DISCUSS}

\section{Vegetative growth}

\section{a. Effect of biopesticides:}

Data presented in Tables (2 and 3) show that inculated potato tuber by Trichoderma harzianum and Bacillus thuringinsis significantly increased the vegetative growth parameters of potato plants compared with the control treatment. The fungi Trichoderma harzianum, being the most effective on both number of aerial stem and leaves per plant, as well as, dry weight of roots, shoots and tubers.

These results are in agreement with these of El-Gamal (2000) who suggested that computability between the Trichoderma and plant kind is important in the success of biological control as some plant root exudates encourage the growth of these biopesticides and some other do not which determines the kind of microorganisms that dominate the rhizosphere microflora and hence antagonistic the pathogenic fungi and the antagonistic ability of the fungal biocontrol, depended on enzymatic producing ability and antibiotic production. These results also, are agreeable with those results reported by Shalaby and Atia (1996); Atia (2005) and Ekin et al. (2009).

Moreover, Abdel-Kader (1997) reported that Trichoderma harzianum enhanced growth directly by production of indole acetic acid (IAA) as growth regulator. Also, the fungi contains a high amount of vitamin B group (Niacin, Pantothenic acid and B6) which may be play a role in the control of the disease by making the plant more healthy and strong in growth which give it a chance to escape from the disease. 


\section{b. Effect of NPK fertilization:}

Data (Tables 2 and 3) also show that plant height, both number of areal stems and leaves/plant, as well as dry weight of roots, shoot, and tuber/plant were significantly increased with increasing $\mathrm{N}-\mathrm{P}_{2} \mathrm{O}_{5}-\mathrm{K}_{2} \mathrm{O}$ up to 40-40-80 kg /faddan, respectively, in both growing seasons.

The stemulative effect of NPK on growth may be due to that, $\mathrm{N}$ is an important element constituent of amino acids, proteins and nucleic acids, phosphorus is a part on nucleic acid (DNA and RNA) and potassium element is very important in overall metabolism of plant, and it has a beneficial effect of water consumption (Mengel and Kirkby, 1978).

Obtained results are going in agreement with those reported by Burton, (1989); Khalil (1990); Meena and Gupta (1996) and El-Banna ( 2004).

\section{c. Effect of interaction between biopesticides and NPK fertilization:}

Data tabulated in Tables (4 and 5) indicate that Trichoderma harziaianum with 40-40-80 $\mathrm{kg} \quad \mathrm{N}-\mathrm{P}_{2} \mathrm{O}_{5}-\mathrm{K}_{2} \mathrm{O} /$ faddan, were significantly increased in most cases, the growth parameter of potato ( morphological characters and dry weight of different parts).

\section{Percentage of natural infection with Phytophthora infestans: a. Effect of biopesticides:}

In this respect, data presented in Table (2) show that the percentage of infected plants was decreased by application of Trichoderma harziaianum, followed by Bacillus thuringinsis.

The mechanism of Trichoderma harziaianum and Bacillus thuringinsis affected potato blight were investigated by Abdel-Gafar et al. (1996) and El-Gamal (2000), who suggested that the effect of Trichoderma harziaianum may be due to its mycelium invaded the inner content of sclerotia causing complete destruction of it. Moreover, Bacillus thuringinsis may be inhibited pathogens by producing antibiotic and fluorescent siderophores. (2003).

These results are in agreement with those reported by Fekry et al.

\section{b. Effect of NPK fertilizers:}

Data tabulated in Table (2) indicate that increasing of $\mathrm{N}-\mathrm{P}_{2} \mathrm{O}_{5}-\mathrm{K}_{2} \mathrm{O}$ fertilizer from $10-10-20$ to $40-40-80 \mathrm{~kg} / \mathrm{fad}$., increased the percentage of diseased plants.

Obtained results are going in agreement with those reported by Mazen (1995) and Fekry et al. (2003). 


\section{c. Effect of interaction between biopesticids and NPK:}

Data presented in Table (4) indicate that the percentage of diseased plant were significantly affected by the interaction between biopesticids and NPK fertilizer levels in both growing seasons, compared with control treatment. Moreover, the percentage of infected plants was decreased by application of Trichoderma harziaianum with the level of 20-20-40, N-P2O5$\mathrm{K} 2 \mathrm{O} \mathrm{kg} / \mathrm{fad}$.

NPK contents in whole plant:

a. Effect of biopesticides:

It is clear from data in Table (6) that $T$. harziaianum gave the highest values of $\mathrm{N}, \mathrm{P}$ and $\mathrm{K}$ contents in whole potato plant, followed by B.thuringiensis and control treatment.

The enhancing effect of $T$. harziaianum in this concern, may be due to its ability to bring insoluble $\mathrm{N}, \mathrm{P}$ and $\mathrm{K}$ in the soil into soluble forms (Subba Rao, 1984). Similar findings were demonstrated by Aly et al. (2000) and Atia (2002).

\section{b. Effect of NPK fertilizers:}

The data in Table (6) illustrate that the highest increments regarding plants content of $\mathrm{N}, \mathrm{P}$ and $\mathrm{K}$ in all cases were observed by increasing $\mathrm{N}, \mathrm{P}_{2} \mathrm{O}_{5}$ and $\mathrm{K}_{2} \mathrm{O}$ from $10-10-20$ to $40-4-80 \mathrm{~kg} / \mathrm{fad}$., in both growing seasons.

The enhancing effect of nitrogen, phosphorus and potassium fertilizers in this concern may be to the available $\mathrm{N}, \mathrm{P}$ and $\mathrm{K}$ in soil and from the high absorbing efficiency of potato roots.

These results are in agreement with those reported by Kaszaki et al. (1995); Anadousi et al. (1998); Abou Hussein et al.(2002) and Behanger et al. (2002).

\section{c. Effect of interaction between biopesticids and NPK:}

Data presented in Table (7) clearly indicate that the concentrations of $\mathrm{N}, \mathrm{P}$ and $\mathrm{K}$ in potato plant were significantly increased by the interaction between T.harziaianum and 40-40-80, $\mathrm{N}-\mathrm{P}_{2} \mathrm{O}_{5}-\mathrm{K}_{2} \mathrm{O} \mathrm{kg} / \mathrm{fad}$., in both growing seasons. 


\section{Yield and its components:}

\section{a. Effect of biopesticides:}

Data in Table (8) shows that, number of tubers/plant, average weight of tubers, yield of small, medium and large tubers as well as total yield/ hectare/ faddan were significantly increased with plant gaurd treatment, followed in descending order by Bacillus and control treatments.

The enhancing effect of plant guard which contains Trichderma harzianum on yield could be attributed to the increase in growth (Table, 2 and 3),number of tubers/plant and average yield/plant as well as, average tuber weight. These results are coincided with those reported by Abdel-Kader (1997) ; Abou Hussein et al. (2002) and Aly et al. (2003).

\section{b. Effect of NPK fertilization:}

Data in Table (8) indicate that number of tuber/plant, average weight of tubers, yield of small, medium and large tubers, as well as, total yield/fad., were significantly increased with increasing the amount of $\mathrm{N}, \mathrm{P}_{2} \mathrm{O}_{5}$ and $\mathrm{K}_{2} \mathrm{O}$ to the highest level, i.e. 40-40-80 kg/faddan in both growing seasons.

The response of yield to rising NPK levels under these conditions may be due to the availability of $\mathrm{N}, \mathrm{P}$ and $\mathrm{K}$ are not sufficient to growing plants in this soil (Table 1). These results are agreeable with those reported by Arsenault et al., 2001; Behanger et al., 2002; Fekry et al., 2003 and Atia, 2005.

\section{c. Effect of interaction between biopesticides and NPK fertilization:}

Data in Table (9) show that yield and its components of potato tubers were significantly affected by interaction between $T$. harzianum and $\mathrm{N}_{-} \mathrm{P}_{2} \mathrm{O}_{5^{-}}$ $\mathrm{K}_{2} \mathrm{O}$ at $40-40-80 \mathrm{~kg} /$ faddan.

\section{Tuber quality}

\section{a. Effect of biopesticides:}

Data tabulated in Table (10) indicate that plant garud gave the highest values of $\mathrm{N}, \mathrm{P}$ and $\mathrm{K} \%$, starch, total carbohydrates and total sugars $\%$ followed in descending order by agarin potato and control treatment. These results are coincided with those reported by Ekin et al. (2009).

\section{b. Effect of NPK fertilization:}

Data in Table (10) show that $\mathrm{N}-\mathrm{P}_{2} \mathrm{O}_{5}-\mathrm{K}_{2} \mathrm{O}$ at 40-40-80 kg/faddan gave the highest values of $\mathrm{N}, \mathrm{P}, \mathrm{K}$, starch, total carbohydrates and total sugars of potato tubers. These results are in agreement with those reported by 
Khalil,1990; Shatilov and Sharov,1992; Javed et al.,1995; Arsenault et al.,2001; Abou Hussein et al.,2002 and Behanger et al.,2002.

\section{c. Effect of interaction between biopesticides and NPK fertilization:}

Interaction between plant guard and $\mathrm{N}-\mathrm{P}_{2} \mathrm{O}_{5}-\mathrm{K}_{2} \mathrm{O}$ at $40-40-80$ $\mathrm{kg} /$ faddan significantly increased $\mathrm{P}$, starch, total carbohydrates and total sugars in potato tubers (Tale 11).

Conclusively, this investigation indicates that plant guard ( $T$. harzianum), and 40-40-80, N- $\mathrm{P}_{2} \mathrm{O}_{5}-\mathrm{K}_{2} \mathrm{O} \mathrm{kg}$ / faddan, as well as, its interaction gave higher growth, chemical composition of potato plants and tuber yield, and also, control of potato late blight comparing to the other treatments.

\section{REFERENCES}

A. O. A. C. (1999). Official Methods of Analysis. $1^{\text {st }}$ ed. Washington DC., USA. Abdel-Ghafar,N.Y.;M.A.T.Amara and N.A.M.Gamil(1996). Biocontrol of some Fuzarium wilt disease using different carier materials for Pseudomonas flurescens . Al-Azhar J. Agric.Res., 23:53-67.

Abdel-Kader, M.M. (1997). Field application of Trichoderma harzianum as biocide control bean root rot diseases. Egypt . J. Phytopathology, 25: 1929.

Abou-Hussein, S. D.; I. El Oksk, T. El Shorbagy and A. M. Gonaa (2002). Effect of cattle manure, biofertilizers and reducing mineral fertilizer on nutrient content and yield of potato plant. Egypt. J. Hort., 29 (1): 99-119.

Aly, A.Z.; Buchenauer, H.; Abou-Zaid, M.I. and Atia, M.M.M. (2000). Studies on tomato late blight disease. Zagazig J. Environmental Research, 2: 229-241- Egypt.

Aly, A.Z.; Buchenauer, H.; Abou-Zaid, M.I.; Shalaby, M.S. and Atia, M.M.M. (2003). Induced resistance against tomato late blight disease by using biological agents. Egyptian J. Phytopathology, 30: 25-43- Egypt.

Anadousi, D.A.N.; B. I. Hattar and M.A. Suwwan (1998). Effect of rate and source of nitrogen on growth, yield and quality of potato under Jordan vally conditions. Potato Abster., 23 (2): 70.

Arsenault, W. J.; A.I. Dabby; C.C.T. George and P. Boswall (2001). Effect of nitrogen application and seed pieces on yield and tuber size in eight potato cultivars. Amer. J. Potato Res., 78: 30-309. 
Atia, M.M.M; Ismail, A.A.; Abd El-Kader, Dawlat A.; El-Said, H.M.; Aly, A.Z. and Abd El-Naby, Entsar E. (2002). The role of cretin bioagents and plant extracts in controlling damping-off and root-rot of pepper and eggplants. The First Conference. of the Central Agricultural Pesticide Laboratory, 3-5 September, Egypt, 348-363,

Atia, M.M.M. (2005). Biological and chemical control of potato late blight. Annals Agric. Sci. Moshtohor, Egypt, 43 (4): 1401-1421.

Behanger, G.; J. R. Walsh; J.E. Richards; P. H. Milburn and N. Zidi (2002). Nitrogen fertilization and irrigation effects on tuber characteristics of two potato cultivars. Amer. J. Potato Res., 79 (4): 269279.

Burton, W. G. (1989). The Potato $3^{\text {rd }}$. Longman Scientific \& Technical, Singapore.

El-Banna, E.N.; S.H. Sarhan and S. A. Ashour(2004). Response of potato plants to different levels of soil applied nitrogen and some foliar sprayed nutrients. J. Product. \& Dev., Egypt., 9 (1):157-166.

El-Gamal, N. G. S. (2000). Biological and chemical control for root diseases of tomato plant. Ph.D. Thesis, Faculty of Agric., Cairo Univ., Egypt, 162p.

Ekin, Z.; F. Oguz; M. Erman and E. Ogun (2009).The effect of Bacillus sp.Osu- 142 inoculation at various levels of nitrogen fertilization on growth, tuber distribution and yield of potato ( Solanum tuberosm L.). African Journal of Biotechnology, 8(18):4418-4424.

Fekry,Wafaa, A.; E .H. Abou El-Salehein and Faten, M. Abdel-Latif (2003). Effect of bioagents, fungicides as well as nitrogen and phosphorus fertilizers on: A-Controlling of white mould disease of bean (Phaseolus vulgaris, L.) and its effect on vegetative growth and chemical composition. Annals of Agric. Sci., Moshtohor, Egypt, 41(4):1501-1520.

Ghanim, A. M.M. (1993). Studies on white mould diseases caused by Sclerotium scleroteorium on some vegetables crops. M.Sc. Thesis, Fac. Agric. El-Azhar Univ., p 83.

Hong, L.; R.Gerado, Y. Xioolong; C.Aian Kathleenand P. L. Jonathan (2001). Effect of phosphorus availability on basal shallowaness in common bean. Plant and Soil, 232: 69-79.

Jackson, M.L. (1973). Soil Chemical Analysis. Prentice Hall of India Private Limited, New Delhi. 
Javed, I. M. S. Chaudhary; M. H. Chaudhary; A. M. Shafig; J. Iqbal; M. Shafig; A. Ghani and A. Hussain (1995). Role of best balanced fertilizer doses in potato production. Proceedings of the National, Seminar held at NARC. Islamabad, Pakistan, 23-29 April, 295-299.

Khalil, M. A. I. (1990). The influence of different sources and levels of NPK fertilizers on the growth, yield and quality of potato plants in sandy soils. Egyptian J. Appl. Sci., 5 (7): 892-897.

Koszaski, Z.; S. Karczmarczyk; C. Podsiadlo and D. Ciazko (1995). Effect of overhead irrigation and nitrogen fertilizer application on potato and soil. 11 chemical composition of the crop. Zeszyty Naukowe Akademii Rolniczej W Szczecinie, Rolanictwo, 59; 23-28.

Mazen,M.M.(1995). Pathological studies on Sclerotinia sclerotiorum affecting some legume crops. M.Sc. Thesis Fac. Agric., Cairo Univ.,Egypt.

Meena, L. R. and M. L. Gupta (1996). Organic manure and nitrogen management in potato under heavy soils of southern Rajasthan. J. Indian Potato Assoc., 23(3-4); 166-167.

Mengel, K. and E.A. Kirkby (1978). Principles Of Plant Nutrition. International Potah Institute, P.O. Box, CH- 3043 Wordbloufen, Bern, Switzerland.

Michel, K. G.; J. K. Hamilton; P. A. Robens and F. Smith(1956).Colorimetric method for determination of sugars and related substances. Analytic Chemistry,28:No.30.

Ranganna, S. (1979). Manual Analysis Of Fruit And Vegetable Products. Tata Mc Grow Hill Publishing Company Limited, New Delhi, 634p.

Shalaby, M.S. and Atia, M.M.M. (1996). Biological and chemical control of watermelon and cantaloupe root-rot in the reclaimed soils. Zagazig $\mathrm{J}$. Agric. Res. , 23 (6): 1023-1039, Egypt.

Shatilov, I.S. and Sharov, A. F. (1992). Production of field crops and indication of soil fertility with application of different rates of organic fertilizer. Izvestiya. Timiryazevsli. Sel, Skokhoze, Yaistvennio Akademii, 1,3 (c.f. Field Crop. Abst., 45-7438).

Snedecor, G.W. and W. G. Cochran (1980). Statistical Methods $7^{\text {th }}$ Ed. Iwo State Univ., USA.

Subba Rao, N. S. (1984). Biofertilizer In Agriculture. Oxford \& IBH Publishing Co., PVT. LTD. New Delhi, India. 


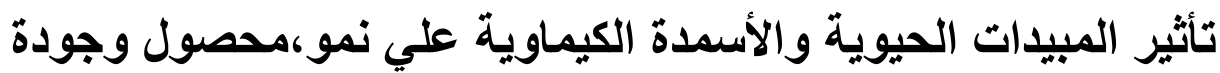

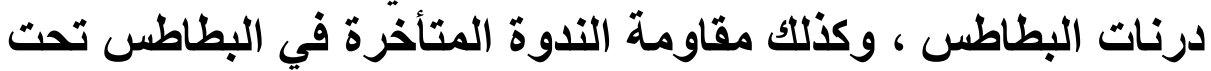 ظروف الأرض الرملية.}

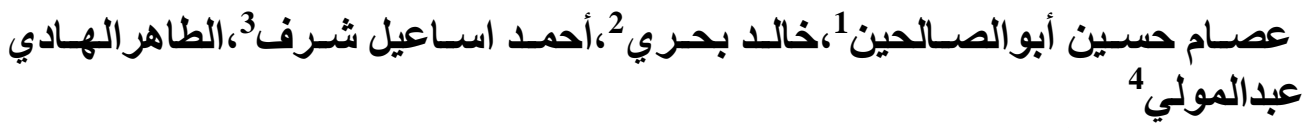
1-قفم الإنتاج النباتي،معهدالكفاية الإنتاجية،جامعة الزقازيقــ مصر.

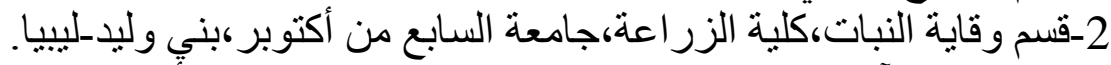

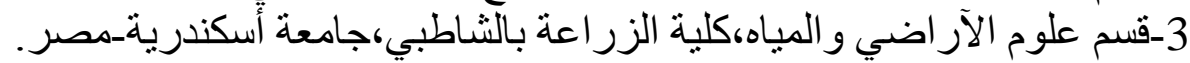

4-قسم المحاصيل، المعهد العالي للمهن الثاملة،الز اوية ـ ليبيا.

أجريت الدر اسة الحالية لدراسـة تأثنير بعض المبيدات الحيويـة (بلانت جـارد ،

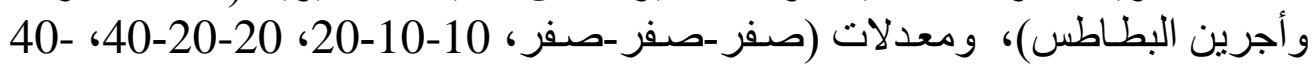

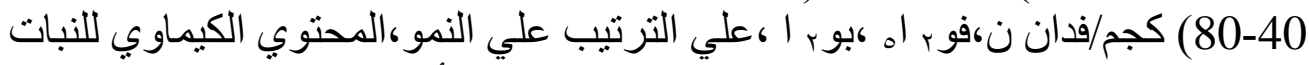

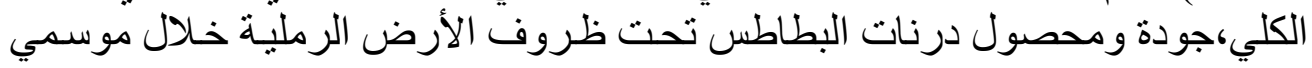
النمو 2007، 2008.

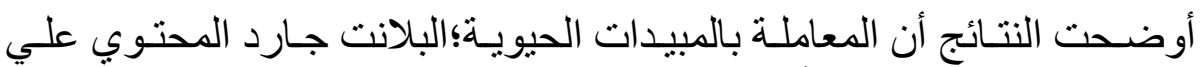

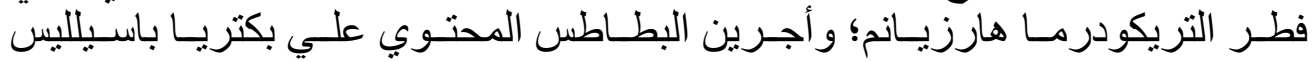

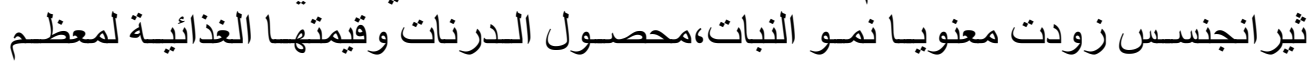

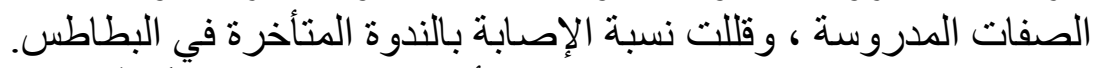

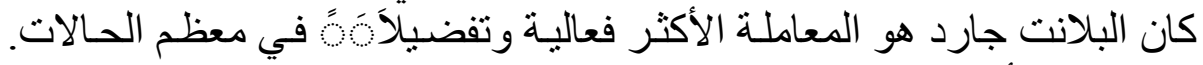

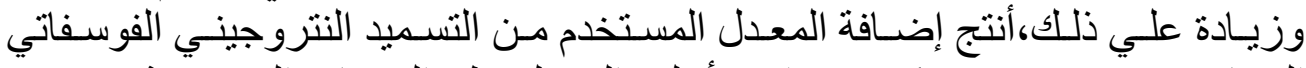

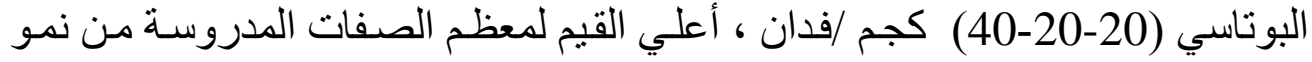

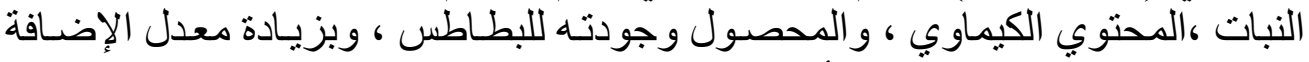

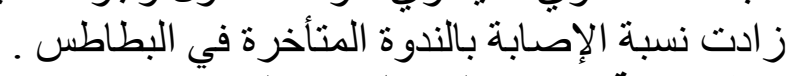

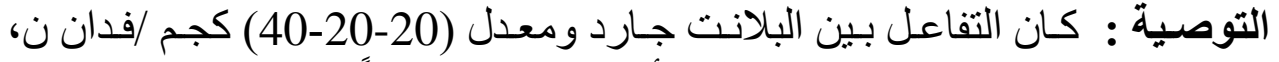
فو اه كبو ا ا،علي الترتيب هو المعاملة الأكثر فعالية وتفضيلاً في معظم الحالات. 